\title{
NSF search advances as budget retreats
}

Washington. Three women - two of whom are active scientists and one a college president - are said to be the leading candidates to succeed Walter Massey as director of the US National Science Foundation (NSF). The rumours of a pending announcement came as President Bill Clinton last week withdrew nearly half of his request for a \$207 million increase this year for NSF that was predicated on its ability to generate a short-term boost in the US economy. It is part of a \$19.5-billion economic stimulus package that Clinton has pared by $\$ 4$ billion in an attempt to appease Republicans in the US Senate.

Those on the 'short list' being considered by presidential advisers are Linda Wilson, president of Radcliffe College in Cambridge, Massachusetts; Rita Colwell, head of the Maryland Biotechnology Institute in Baltimore; and Sandra Faber, professor of astronomy at the University of California, Santa Cruz. Wilson has refused several requests for an interview, while Colwell and Faber declined to answer whether they were being considered.

Colwell and Faber, along with others on a longer, earlier list, believe that the next director will be important in deciding whether NSF assumes a larger role in addressing strategic needs while retaining its primary mission to support academic research. Last summer, the US Congress urged NSF to spend a larger part of its $\$ 2.7$-billion budget in that way, and last autumn a commission appointed by Massey issued a controversial report, encouraging NSF to do both and to foster closer ties between industry and university researchers.

In today's climate of fiscal austerity, the balance between the two becomes paramount. About 55 per cent of NSF's supplementary budget request - and a similar amount of its overall budget - is spent on six areas that are seen as helping to strengthen the US economy, from advanced manufacturing to biotechnology, or that address national goals, such as high-performance computing or understanding global climate change. Massey thinks such a balance "is about right". But he left last month, two years into a six-year term, to become provost of the University of California system, and a new director will have some freedom to choose which course to follow.

Other issues are equally pressing. One is how to pay for large and costly instrumentation and facilities - from telescopes to ocean-going research vessels - without cutting too deeply into the number and size of grants to individual investigators, some of whom rely on such equipment for their work. "The cost of new facilities is the critical problem facing astronomy", says Faber, "and I really don't know if there is a way out."

A related problem is the growing use by universities of lobbyists to win funding for new laboratories and buildings not requested by the funding agency, the so-called "porkbarrel' projects. Says Faber, "the key to a happy community is to ensure that the procedures for approval are above reproach".

Another problem is the rising number of investigators competing for grants and the resulting decline in funding rates - now less than one in four in some fields. This factor competes for attention with the increasing cost of doing research, and together they could more than swallow up whatever additional funding is obtained, leaving little room for new initiatives. For example, NSF has promised to use almost half of whatever extra funding it receives this year to increase the size of grants rather than to make new awards, but each year the NSF director faces pressure on both fronts.

The job has considerable appeal. As head of an independent agency, the NSF director does not have to deal with the same suffocating bureaucracy that hinders the National Institutes of Health, for example, and potentially he or she has greater access to the White House. In addition, the six-year term offers more job security than most presidential appointments. "It's a job that any US scientist or engineer would find interesting", says Donald Langenburg, chancellor of the University of Maryland and a former deputy NSF director who is thought to be a strong contender if the president decides not to appoint a woman.

\section{DNA testing helps British bring better pig to market}

London. A leaner and happier pig is the latest exhibit in an attempt by Britain's Ministry of Agriculture, Fisheries and Food to persuade the public to accept the application of molecular genetics to animal breeding.

The new pig is guaranteed to be free of the 'halothane' gene, a genetic mutation that traditionally could be detected solely through exposure to the anaesthetic vapour halothane. The mutation is linked to increased leanness in meat and has become increasingly common as pigs are bred for this characteristic. But it has also been found to reduce the capacity of meat to hold water (an undesirable trait in keeping meat moist in shops) and to increase the animal's susceptibility to stress.

The gene was identified two years ago by scientists at the University of Toronto in Canada. The mutation itself was already in the process of being bred out in a programme carried out by the Cotswold Pig Development Company Ltd that began in the early 1980 s. However, since the halothane test works only for individuals in which the mutation is expressed - and not those that are merely carriers - the ultimate success of the project relied on the development of a DNA detection kit based on the Canadian discovery.

The resulting pig, which is guaranteed to be free of the mutation, is said by Cotswold to be the first application of DNA technology in farm animals. The company believes that an important advantage, besides producing pigs that are more profitable for farmers and whose meat is more attractive in supermarkets, is a reduced level of stress for the pig itself. "We should be proud that science can deliver this kind of advantage, and not be frightened of it", says John Gummer, the agriculture minister.

Wary of potential protests from animal rights group, the company is quick to point out that the development of the new pig has not required the use of genetic engineering. Animal welfare groups admit that they are impressed by the elimination of a genetic trait which makes the pig less prone to stress but that it has not reduced their distrust of genetic engineering more

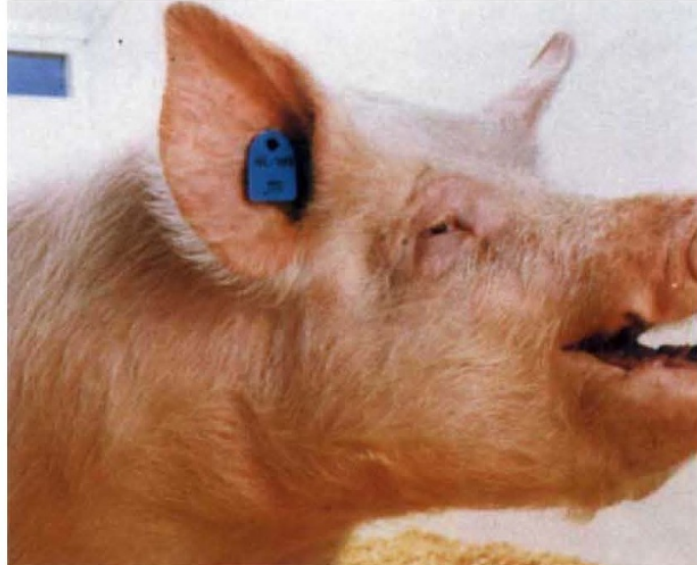

Cotswold boar with a tag in its ear declaring it to be free of the mutation.

generally. "We are still concerned about the wider applications of these new techniques, since they put a foot on the accelerator of our ability to produce new varieties of animals purely for commercial reasons", says Martin Potter of the Royal Society for the Prevention of Cruelty to Animals.

David Dickson 